\title{
MIR19A Gene
}

National Cancer Institute

\section{Source}

National Cancer Institute. MIR19A Gene. NCI Thesaurus. Code C80717.

This gene is involved in the regulation of gene expression and plays a role in the development of hepatocellular, lung and thyroid carcinomas, plasma cell myeloma, medulloblastoma, Cowden's syndrome and spinocerebellar ataxia. 